\title{
ASSESSMENT OF CAMBIAL ACTIVITY AND XYLOGENESIS BY MICROSAMPLING TREE SPECIES: AN EXAMPLE AT THE ALPINE TIMBERLINE
}

\author{
Sergio Rossi*, Annie Deslauriers and Tommaso Anfodillo \\ Treeline Ecology Research Unit, Dipartimento Territorio e Sistemi Agro-Forestali, Università degli \\ Studi di Padova, Viale dell’Università 16, I-35020 Legnaro (PD), Italy \\ (*Corresponding author: E-mail: sergio.rossi@unipd.it)
}

\begin{abstract}
SUMMARY
Mechanisms of cell production and maturation and dynamics of xylem formation have been widely studied in trees in order to better characterize stem radial growth. Histological analyses have been used in this study to describe cambial activity and xylem cell differentiation in Larix decidua, Pinus cembra and Picea abies at the Alpine timberline. Wood microcores were collected weekly from April to October 2003 and cross sections prepared to distinguish xylem cells of the growing tree ring and to determine the number of cells in the cambial zone, radial cell enlargement, secondary wall thickening and lignification and the number of mature tracheids. The anatomical changes characterizing the phases of xylem cell production and differentiation during the year are described and discussed. All species showed the same trend of xylem formation. Three delayed bell-shaped curves and an S-shaped curve were observed for cambium, enlarging and wall thickening cells and mature cells, respectively. Cells divided in the cambial zones from April-May to August, depending on the species. From 100 to 130 days were required to complete cell differentiation. Tree-ring formation ended during September. The average periods spent on radial enlargement, and secondary cell wall thickening and lignification were estimated at 7-10 and 20-25 days, respectively.
\end{abstract}

Key words: Cambium, cell differentiation, lignification, wall thickening.

\section{INTRODUCTION}

In temperate and boreal ecosystems, radial growth in conifers occurs through the yearly formation of a layer of xylem cells originating from the cambial meristem and enveloping the wood cylinder of the stem. The economic importance of wood production has always encouraged the study of xylogenesis processes in order to assess the period when earlywood and latewood growth occurs and the mechanisms involved in xylem growth (Downes et al. 2002). However, understanding of the temporal dynamics of cell production and maturation require specific wood anatomy investigations performed on developing cells during xylem formation (Wimmer 2002). 
Basically, wood formation is a cyclic and gradual proliferation of xylem cells in which phases of cell production and differentiation are separated in space and time. Differentiation follows cell division occurring in the cambium. However, as the new derivative cells begin differentiation, other cells are produced. During the growing season, cells located in the same radial file can be at different stages of maturation and thus also the different biochemical processes involved in xylem formation are in different stages. The timings of differentiation phases determine specific anatomical characteristics of the xylem (Whitmore \& Zahner 1966; Wodzicki 1971; Denne 1974; Denne \& Dodd 1981) and, in turn, technological features of the wood (Tsoumis 1991; Butterfield 2003). Analyses of radial growth processes must distinguish cell production and differentiation in order to correctly characterize the factors affecting each stage of xylogenesis.

In biology, there are several interconnected levels of study involving anatomical, molecular and biochemical analyses. Advanced molecular techniques have recently been developed for xylogenesis. However, knowledge of cell physiology is still inadequate for interpreting the information collected at the molecular level, and studies on genetic modifications are underway, while basic studies on xylogenetic processes and wood production are being neglected (Chaffey 2002). In the past decade, xylogenesis has been studied in non-woody plants like Arabidopsis (Berleth et al. 2000; Chaffey et al. 2002) and Zinnia elegans (Ferrer \& Ros Barceló 1999; Groover \& Jones 1999; Ros Barceló et al. 2002), applying molecular techniques. However, precise information on radial growth processes in a forest environment can only be obtained from woodproducing plants like trees, but this type of information is still largely incomplete or even lacking (Savidge 2003).

The characteristic pattern of xylem cell production and differentiation organizes the vascular elements in radial files. The radial sequence of cells corresponds to the temporal sequence of appearance in the trees, allowing wood formation to be assessed over different intra-annual time scales depending on the resolution required by the analysis, from a few hours (Ford et al. 1978) to one week (Deslauriers et al. 2003; Rossi et al. 2006b), to several weeks (Bäucker et al. 1998; Rao \& Rajput 1999). A precise description of the period of wood formation allows the days spent in differentiation by each cell to be estimated (Wodzicki 1971; Horacek et al. 1999; Rossi et al. 2003). Moreover, linking xylogenesis with the intra-annual variations of climatic variables can lead to a better understanding of the factors affecting wood production and mechanisms regulating radial growth. Given the importance of this research field in ecophysiology (Deslauriers et al. 2003) and forestry (Downes et al. 2002), intra-annual analyses of wood formation are being developed notwithstanding the complex sampling designs, problematic data elaborations and meticulous microscopic observations (Wodzicki 1971; Barlow et al. 2002; Wimmer 2002).

In this paper, a technical approach to assess xylogenesis with microsamplings is described and a step-by-step description is given of the different phases of wood formation in order to reconstruct precise timings of cell differentiation in the stems of three conifer species. 


\section{MATERIAL AND METHODS}

The study area was located at the timberline (2080 $\mathrm{m}$ a.s.1.) in the eastern Italian Alps $\left(46^{\circ} 27^{\prime} \mathrm{N}, 12^{\circ} 08^{\prime} \mathrm{E}\right)$. Fifteen adult trees of Larix decidua Mill., Pinus cembra L. and Picea abies (L.) Karst. were chosen in a permanent plot of $500 \mathrm{~m}^{2}$ near the Cinque Torri mountains (Cortina d'Ampezzo, Italy). Trees were selected in 2001 after having assessed growth rate homogeneity by counting the number of tracheids in the tree rings of three preceding growing seasons, and the absence of reaction wood (Antonova \& Stasova 1993; Deslauriers et al. 2003). Tree heights, ages and diameters at breast height are reported in Table 1.

Table 1. Mean and standard deviation of tree heights (h), diameters at breast height (DBH) and ages of sampled trees.

\begin{tabular}{lccc}
\hline Species & $\mathrm{h}(\mathrm{m})$ & $\mathrm{DBH}(\mathrm{cm})$ & Age \\
\hline Larix decidua & $11.6 \pm 1.0$ & $26.8 \pm 4.8$ & $60.6 \pm 18.7$ \\
Pinus cembra & $10.1 \pm 0.7$ & $29.2 \pm 8.6$ & $60.4 \pm 7.9$ \\
Picea abies & $10.4 \pm 0.6$ & $22.4 \pm 6.2$ & $45.0 \pm 8.6$ \\
\hline
\end{tabular}

From April to October 2003, wood microcores (2.4 mm in diameter) were randomly collected each week around the stems at DBH $(1.3 \mathrm{~m})$ using an increment puncher (Forster et al. 2000). In Larix decidua and Pinus cembra, the thick dead outer bark was removed before sampling. The samples usually contained the preceding 4-5 tree rings and the developing annual layer with the cambial zone and adjacent phloem. Immediately after sampling, the microcores were placed in Eppendorf microtubes with an ethanol solution ( $50 \%$ in water) and stored as soon as possible at $5{ }^{\circ} \mathrm{C}$ in order to avoid tissue deterioration. All samples were then processed within a maximum of $2-3$ weeks.

Each sample was oriented by marking the transversal side with a pencil under a stereo-microscope at $\times 10-20$ magnifications. The microcores were dehydrated with successive immersions in ethanol and D-limonene, embedded in paraffin according to Rossi et al. (2006a) and transverse sections of 6-10 $\mu \mathrm{m}$ thickness were cut with a rotary microtome. Sections were stained with cresyl violet acetate $(0.16 \%$ in water) and observed immediately with visible and polarized light at $\times 400-500$ magnifications to distinguish the developing xylem cells. For each sample, the radial number of cells in the cambial zone, radial enlargement phase, cell wall thickening phase, and mature cells were counted along 3 files (Skene 1969; Antonova \& Shebeko 1981; Antonova et al. 1995; Deslauriers et al. 2003). In cross section, cambial initials constitute a onecell-width layer (Timell 1980; Tsoumis 1991). However, the initial cells are associated with undifferentiated derivatives, anatomically undistinguishable from the cambium (Wilson 1964; Kramer \& Kozlowski 1979; Savidge 2000). For this reason, the term cambial zone is used for the entire layer constituted of initial cells and derivatives (Mahmood 1971). 
Cell number in the 3 files was averaged for each tree and used to assess overall timing of xylem growth. In spring, when at least one cell was observed in the enlarging phase, xylem formation was considered to have begun. In late summer, when no other cell was observed in wall thickening and lignification, xylem formation was considered complete. After having assessed the homogeneity of the variances among trees by Levene's test, analysis of variance (ANOVA) and Welch's ANOVA were performed in order to compare means for the three species.

From the total number of cells in each differentiation phase and mature cells, the approximate date of onset and number of days spent in radial enlargement and cell wall thickening by each consecutive tracheid was estimated according to Wodzicki (1971). The methodology is based on differences between (i) total cell number (radial elongation, wall thickening and mature cells), (ii) wall thickening and mature cells and (iii) mature cells. All the algorithms were calculated with data fitted using the Gompertz function as described in Deslauriers et al. (2003). The Gompertz equation, fitted to establish the cell increase profile for each species, was defined as:

$$
y=A \exp \left[-\mathrm{e}^{\beta-\kappa t}\right]
$$

where $y$ is the weekly cumulative sum of cells, $t$ the time computed in Julian days, $A$ the upper asymptote (maximum growth expressed as cell number), $\beta$ the $x$-axis placement parameter and $\kappa$ the rate of change of the shape. Examination of the R-square, the asymptotic t-statistic for the parameters, and plots of the residual showed that the Gompertz function was appropriate for describing growth and time relationships, as also reported in Rossi et al. (2003) and Rossi et al. (2006b).

\section{RESULTS AND DISCUSSION}

\section{Dynamics of cambial activity}

In cross section, cells in the cambial zone were characterized by thin cell walls and small radial diameters (Fig. 1A). The initial cells divided periclinally, producing xylem and phloem mother cells that divided again through repeated tangential divisions occurring on both sides of the radial file leading the cambial zone to appear expanded (Fig. 1B). Derivative cells gradually developed, assuming typical characteristics of a phloem or xylem cell and achieving the level of specialization and physiological stability characterizing the components of plant tissues.

Cambial activity and radial growth in boreal and temperate regions is periodic, alternating periods of growth with winter inactivity (Iqbal 1994; Fujii et al. 1999). Because of this, the number of cambial cells alters during the year (Fig. 2). In autumn and winter, when there is no cell production, dormant cambium is constituted by a minimum number and close-together group of cells, generally 6-8 in the three studied species (Fig. 1A \& 2). In spring, cambial cells swell and expand radially, radial cell walls grow thin, cytoplasm assumes shinier and less densely granulate features and the nuclei enlarge (Fahn \& Werker 1990). Inside the protoplasts, the numerous small vacuoles gradually merge, forming one or two larger vacuoles (Oribe \& Kubo 1997). The swelling is followed by periclinal divisions and production of phloem and xylem 

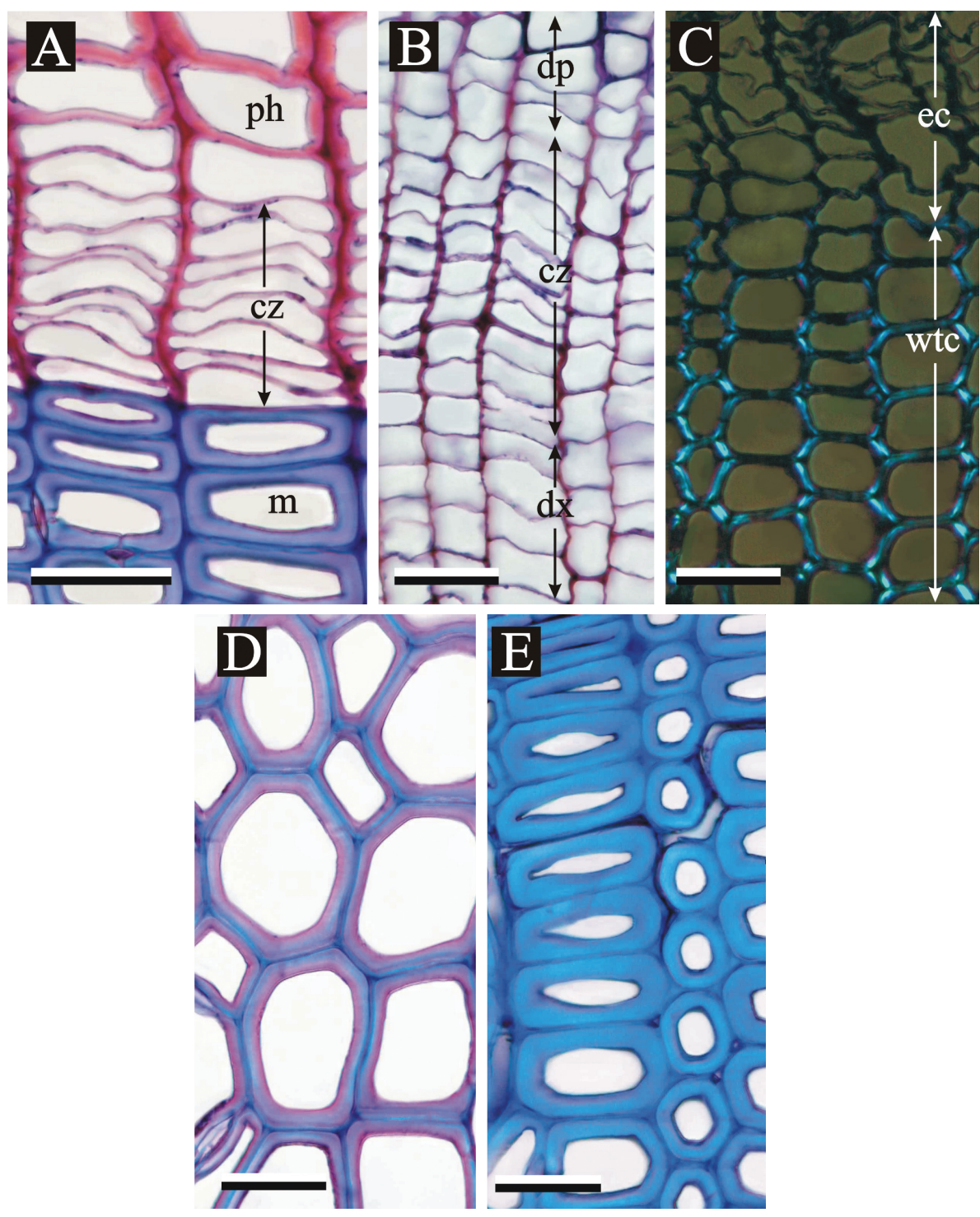

Fig. 1. - A: Cross section of Pinus cembra stem in winter; mature tracheid (m), cambial zone (cz), phloem cell (ph). - B: Cambial zone (initial cells and derivatives) during the growing season in Picea abies; developing xylem (dx), cambial zone (cz), developing phloem (dp). - C: Wall thickening and enlarging cells of Picea abies under polarized light; wall thickening cells (wtc), enlarging cells (ec). - D: Earlywood of Larix decidua with partially lignified cells. - E: Mature cells of latewood in Larix decidua. - Scale bars $=20 \mu \mathrm{m}$. 
derivatives. At the end of April, the cambial zone in Pinus cembra already showed 9-10 cells (Fig. 2). On the contrary, in Larix decidua and Picea abies, the number of cambial cells increased in mid-May. The cambium cell number increased to 10-14 during the period of maximum growth activity in May-June, as also reported by Bannan (1962) for slow growth rate trees. Once annual activity has ended, the cambium stops dividing and the number of cells in the cambial zone reduces to a minimum value corresponding to quiescence conditions around the middle of August (Fig. 2).
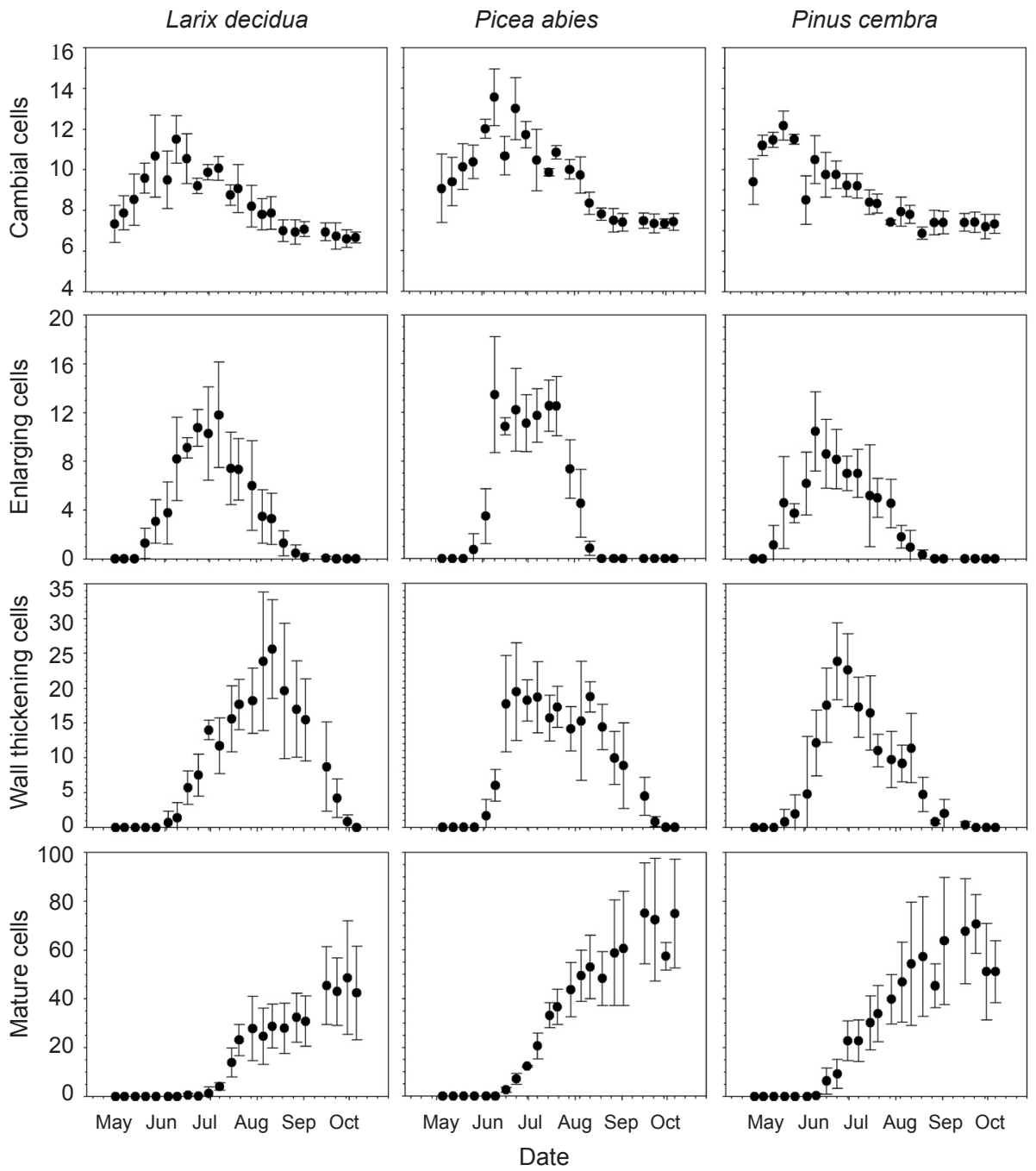

Fig. 2. Number of cells observed in the cambial zone, enlargement phase, wall thickening phase, and number of mature xylem cells in Larix decidua, Picea abies and Pinus cembra during 2003. Dots and bars represent average number of cells and standard deviations among five trees, respectively. 


\section{Cambial cells versus differentiating cells}

The three species showed the same trend of xylem formation and the radial files of differentiating cells had an evident pattern of variation during the year (Fig. 2). At the start of the growing season (i.e. from April 29 to May 12 for Larix decidua), when only cell division occurred, the cambial zone increased. Once cell enlargement began (May 12 in L. decidua), an equilibrium between cell division and differentiation determined a temporary arrangement of the width of the cambial region. When the division rate slowed down (June 16-June 23 in L. decidua), the cambial zone began to narrow as the rate of cell differentiation was faster than cell division and the radial number of enlarging cells for L. decidua increased to $11.8 \pm 4.3$ on July $7^{\text {th }}$. Analogous linkages between the successive developmental phases were observed.

According to Fahn and Werker (1990), the observed variations in cell numbers during the development phases are strictly interconnected. Cells in the same differentiation phase constitute a queue (Ford et al. 1978). Intra-annual variations in rate of cell division and differentiation determine variations among the cell queues, resulting in a typical annual pattern consisting of three delayed bell-shaped curves (cambial, cell enlargement and wall thickening cells) and a growing S-shaped curve (mature cells) (Fig. 2). The bell-shaped patterns are connected with the number of cells passing through each differentiation phase, whereas the $\mathrm{S}$-shaped curves are associated with the gradual accumulation of mature cells in the tree ring.

\section{Dynamics of cell differentiation}

During development, the cambial derivatives alter both morphologically and physiologically, gradually assuming definite features. In other words, the derivatives differentiate into the specific elements of the stem tissues. In xylem cells, this process is associated with changes in both cell wall composition and organization. The three species showed clear variations in the onset of tree-ring formation (Fig. 3), corresponding to the first cell observed in the enlargement phase. The earliest start of radial enlarge-

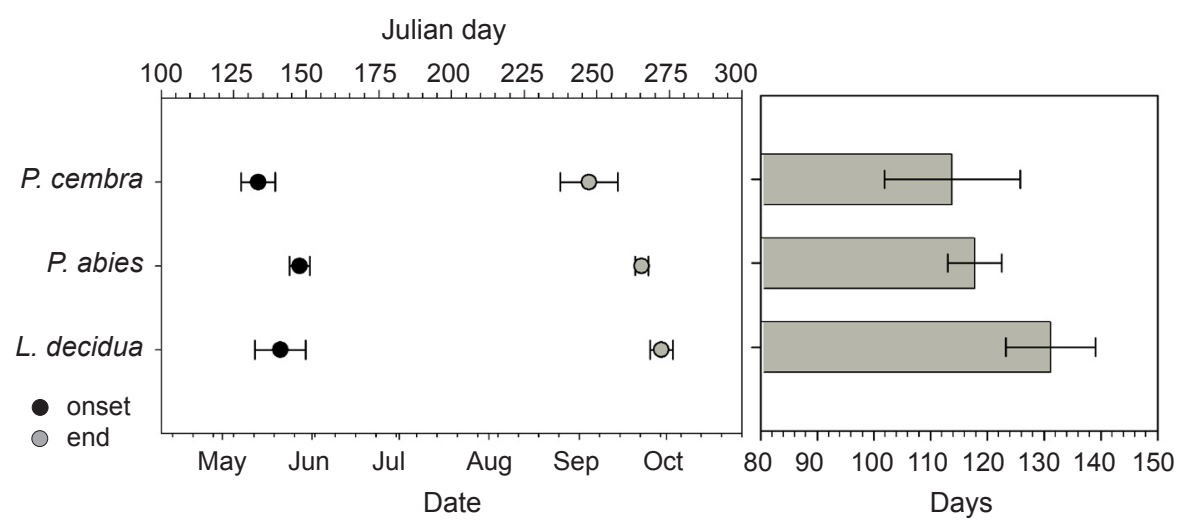

Fig. 3. Onset, end (left) and overall duration (right) of wood formation for Larix decidua, Picea abies and Pinus cembra. Horizontal bars indicate standard deviation among five trees when timing was computed in Julian days. 
ment was observed in tracheids of Pinus cembra in mid-May and tracheids in Picea abies were the last to start radial enlargement (ANOVA, $F=6.18, p<0.05$ ). The end of xylogenesis corresponds to the conclusion of lignification. Tree-ring formation at the Alpine timberline can be considered as being concluded at the end of September for all the studied species. A high standard deviation among trees was observed in Pinus cembra and a very low variation in Picea abies. For this reason, the assumption of equal within-group variances was not respected (Levene's test, $\mathrm{F}=9.63, \mathrm{p}<0.01$ ) and Welch's ANOVA were performed. In this case, significant differences among species were observed $(\mathrm{F}=14.6, \mathrm{p}<0.01)$, with earliest ending of wall lignification for Pinus cembra in the first 10 days of September. The duration of wood formation included all the differentiation phases from the onset of cell enlargement to the end of maturation. About four months were required to complete tree-ring formation in the treeline species (Fig. 3) and the longest duration was observed in Larix decidua, with 131 days of xylogenesis (ANOVA, $\mathrm{F}=2.14, \mathrm{p}<0.05$ ).

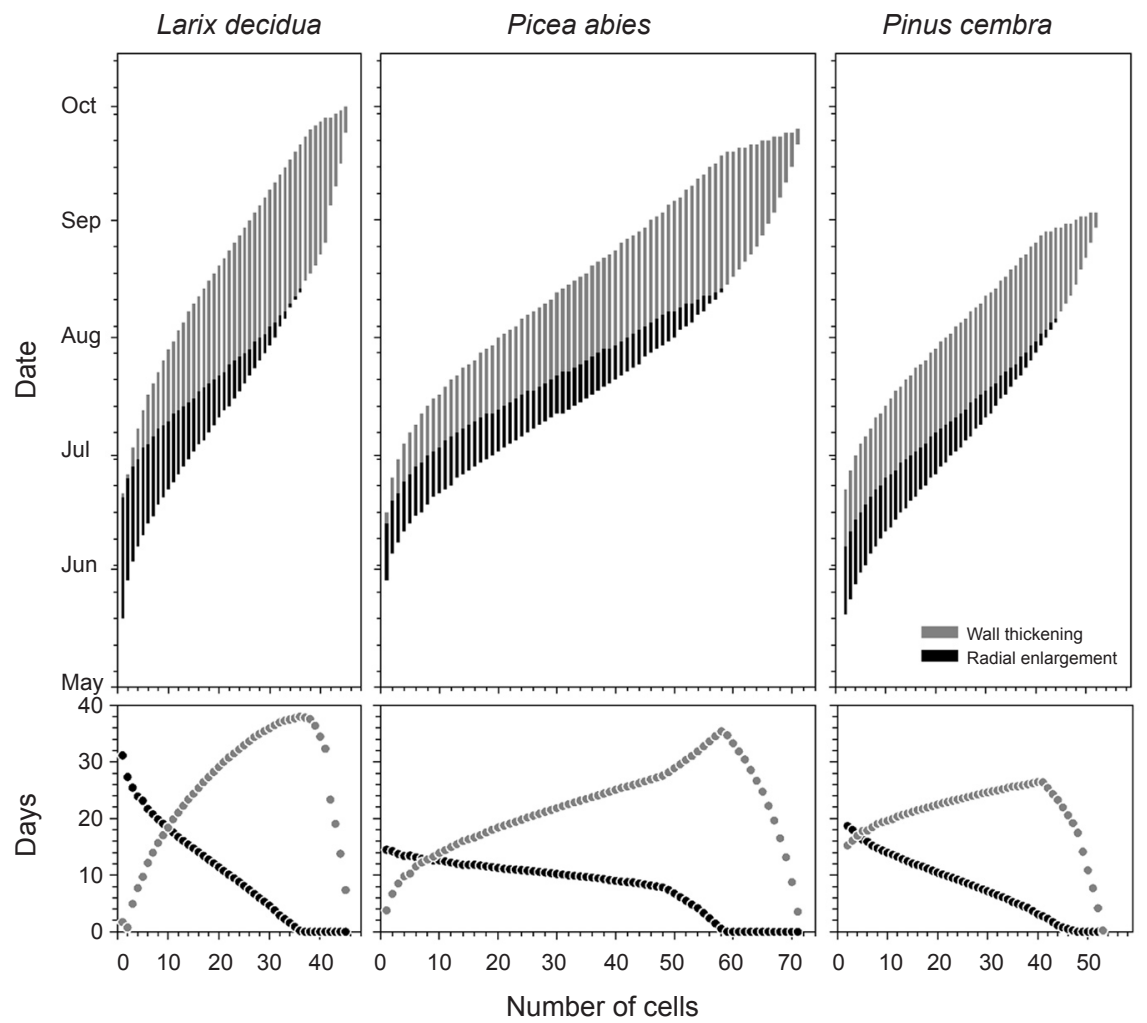

Fig. 4. Timings (above) and days spent (below) in radial cell enlargement (black) and cell wall thickening (grey) for each consecutive tracheid produced in 2003 in Larix decidua, Picea abies and Pinus cembra. 
During cell enlargement, the derivatives consist of a protoplast still enclosed in the thin and elastic primary wall. Following positive turgor increase by water movement into the vacuoles, the cell wall stretches, increasing the radial diameter of the tracheid and, consequently, the lumen area. This process occurs despite strong compression, the cells being enclosed between xylem tissues and bark and deformed files of tracheids could be generally observed (upper side in Fig. 1C).

The estimated average periods spent in radial enlargement were 10.2, 7.9 and 8.1 days for Larix decidua, Picea abies and Pinus cembra, respectively. Similar trends were observed in the three species among the successively formed tracheids. The persistence of the cells in radial enlargement gradually decreased along the radial file from 14-25 days in the first earlywood tracheids to very few days in the last cells (Fig. 4). For tracheids of Picea abies growing at $625 \mathrm{~m}$ a.s.1. in Central Europe, Horacek et al. (1999) estimated periods of 15-35 days spent in radial enlargement. However, even if requiring a longer enlargement phase, cells reached similar size, up to $40-50 \mu \mathrm{m}$ measured by Horacek et al. (1999) versus $40 \mu \mathrm{m}$ observed for $P$. abies trees in the study area (Rossi 2003). During radial enlargement, cell volume expansion occurs through pulsing change in water potential leading to decreasing enlargement rates as a function of cell age (Pritchard 1994; Antonova et al. 1995). According to the model proposed by Fritts et al. (1999), radial tracheid growth depends more on the rate of development, especially at the onset of tracheid growth when the rate is higher, than on the duration of the process.

In cross section, observations under polarized light discriminated between enlarging and cell wall thickening cells. Because of the arrangement of the cellulose microfibrils, the developing secondary walls shone when observed under polarized light (Fig.1C, below). Instead, shining was not observed in the enlargement zones (Fig. 1C, above). This is a common characteristic of enlarging cells still composed of just primary wall (Donaldson 1991; Abe et al. 1997).

Once their final size had been reached, the cells began maturing through cell wall thickening and lignification. These processes are coordinated by the expression of several genes specifically involved in the synthesis of cell wall constituents, such as polysaccharides, structural lignins and proteins (Plomion et al. 2001). The deposition of microfibrils of cellulose and hemicelluloses starts the formation of the three layers constituting the secondary wall. The lignin is placed in the intercellular layers and the intermicrofibril spaces of the wall thereby cementing the microfibrils together. The progress of cell wall lignification was detected by staining the sections with cresyl violet acetate reacting with the lignin (Kutscha et al. 1975; Antonova \& Shebeko 1981). The observation of lignin incorporation with light microscopy was in agreement with results obtained using electron microscopy and UV-microspectrophotometry (Gričar et al. 2005). Lignification was shown by a colour change from violet (unlignified secondary cell walls, Fig. 1D) to blue (lignified cell walls, Fig. 1E). At first, lignin deposition was observed at the cell corners on the primary wall, then extending on intercellular layers and, finally, on the secondary wall. The lignification pattern was the same in all species and could be related to the spread of the lignin precursors diffusing through the secondary wall to the external parts of the cell wall (Donaldson 1991). The lignin 
distribution within developing cells corresponds to the delay between the polysaccharide deposition and lignin incorporation (Gindl et al. 2000; Gričar et al. 2005). The final stages of maturation involve autolysis of the protoplast. The blue colour over the whole cell wall indicated the end of lignification and the attainment of the mature stage for the tracheid.

The average period spent in secondary cell wall thickening and lignification was estimated as 25.4, 21.5 and 20.6 days for Larix decidua, Picea abies and Pinus cembra, respectively. The duration of this differentiation phase was shorter in the cells located at the beginning of the tree ring, with values ranging from 5 to 15 days and with higher values (up to 37 days) estimated in Larix decidua for tracheids 33-38 (Fig. 4). Reductions in the duration of wall thickening in the latest latewood cells were observed in the three species. The duration pattern of cell wall thickening corresponded to variations observed in Larix decidua, Picea abies and Pinus cembra in wall thickness culminating in latewood but decreasing in the last cells of the tree ring (Rossi 2003). Although rates of wall thickness are reported as being higher earlier in the growing season (Wodzicki 2001), the reduction in radial diameter of the successive tracheids along a tree ring reduces the surface for wall deposition. For this reason, the final cell wall thickness is closely related to the duration of wall thickening, thus also determining the change from earlywood to latewood cells (Wodzicki 1971; Denne 1974; Uggla et al. 2001).

To conclude, wood formation is a complex phenomenon involving several cell production and differentiation phases with specific development rates and durations. Treering growth cannot be directly observed or measured. However, anatomical features of the differentiating xylem cells allow cell division in the cambial zone to be separated from postcambial growth, and patterns of cell enlargement, secondary wall thickening and lignification to be assessed. Information recorded with appropriate time scales during the growing season can thus be used to estimate dynamics of cambial activity and times spent on xylem cell maturation.

\section{ACKNOWLEDGEMENTS}

Data reported in this work were produced with MIUR-PRIN 2000 and 2002. The authors wish to thank M. Mazzaro and R. Menardi for technical support and K. Čufar and two anonymous referees for their constructive comments on the manuscript.

\section{REFERENCES}

Abe, H., R. Funada, J. Ohtani \& K. Fukazawa. 1997. Changes in the arrangement of cellulose microfibrils associated with the cessation of cell expansion in tracheids. Trees 11: 328-332. Antonova, G.F., V.P. Cherkashin, V.V. Stasova \& T.N. Varaksina. 1995. Daily dynamics in xylem cell radial growth of Scots pine (Pinus sylvestris L.). Trees 10: 24-30.

Antonova, G.F. \& V.V. Shebeko. 1981. Applying cresyl violet in studying wood formation. Khimiya Drevesiny 4: 102-105.

Antonova, G.F. \& V.V. Stasova. 1993. Effects of environmental factors on wood formation in Scots pine stems. Trees 7: 214-219.

Bannan, M.W. 1962. The vascular cambium and tree ring development. In: T.T. Kozlowski (ed.), Tree growth: 113-138. Ronald Press, New York. 
Barlow, P.W., P. Brain \& S.J. Powers. 2002. Estimation of directional division frequencies in vascular cambium and in marginal meristematic cells of plants. Cell Prolif. 35: 49-68.

Bäucker, E., C.T. Bues \& M. Vogel. 1998. Radial growth dynamics of spruce (Picea abies) measured by micro-cores. IAWA J. 19: 301-309.

Berleth, T., J. Mattsson \& S. Hardtke. 2000. Vascular continuity and auxin signals. Trends Plant Sci. 5: 387-393.

Butterfield, B.G. 2003. Wood anatomy in relation to wood quality. In: J.R. Barnett \& G. Jeronimidis (eds.), Wood quality and its biological basis: 30-52. Oxford, UK.

Chaffey, N. 2002. Why is there so little research into the cell biology of the secondary vascular system of trees? New Phytol. 153: 213-223.

Chaffey, N., E. Cholewa, S. Regan \& B. Sundberg. 2002. Secondary xylem development in Arabidopsis: a model for wood formation. Physiol. Plantarum 114: 594-600.

Denne, M.P. 1974. Effects of light intensity on tracheid dimensions in Picea sitchensis. Ann. Bot. 38: 337-345.

Denne, M.P. \& R.S. Dodd. 1981. The environmental control of xylem differentiation. In: J.R. Barnett (ed.), Xylem cell development: 236-255. Castle House Publications Ltd., Kent.

Deslauriers, A., H. Morin \& Y. Begin. 2003. Cellular phenology of annual ring formation of Abies balsamea in the Quebec boreal forest (Canada). Can. J. For. Res. 33: 190-200.

Donaldson, L.A. 1991. Seasonal changes in lignin distribution during tracheid development in Pinus radiata D. Don. Wood Sci. Technol. 25: 15-24.

Downes, G.M., R. Wimmer \& R. Evans. 2002. Understanding wood formation: gains to commercial forestry through tree-ring research. Dendrochronologia 20: 37-51.

Fahn, A. \& E. Werker 1990. Seasonal cambial activity. In: M. Iqbal (ed.), The vascular cambium: 139-154. John Wiley \& Sons, New York.

Ferrer, M.A. \& A. Ros Barceló. 1999. Differential effects of nitric oxide on peroxidase and $\mathrm{H}_{2} \mathrm{O}_{2}$ production by the xylem of Zinnia elegans. Plant Cell Environ. 22: 891-897.

Ford, E.D., A.W. Robards \& M.D. Piney. 1978. Influence of environmental factors on cell production and differentiation in the earlywood of Picea sitchensis. Ann. Bot. 42: 683-692.

Forster, T., F.H. Schweingruber \& B. Denneler. 2000. Increment puncher: a tool for extracting small cores of wood and bark from living trees. IAWA J. 21: 169-180.

Fritts, H.C., A. Shashkin \& G.M. Downes 1999. A simulation model of conifer ring growth and cell structure. In: R. Wimmer \& R.E. Vetter (eds.), Tree-ring analysis: 3-32. CAB International, Oxon, UK.

Fujii, T., A. Tukau Salang \& T. Fujiwara. 1999. Growth periodicity in relation to the xylem development in three Shorea spp. (Dipterocarpaceae) growing in Sarawak. In: R. Wimmer \& R.E. Vetter (eds.), Tree-ring analysis: 169-183. CAB International, Oxon, UK.

Gindl, W., M. Grabner \& R. Wimmer. 2000. The influence of temperature on latewood lignin content in treeline Norway spruce compared with maximum density and ring width. Trees 14: 409-414.

Gričar, J., K. Čufar, P. Oven \& U. Schmitt. 2005. Differentiation of terminal latewood tracheids in silver fir trees during autumn. Ann. Bot. 95: 959-965.

Groover, A. \& A.M. Jones. 1999. Tracheary element differentiation uses a novel mechanism coordinating programmed cell death and secondary cell wall synthesis. Plant Physiol. 119: 375-384.

Horacek, P., J. Slezingerova \& L. Gandelova. 1999. Effects of environment on the xylogenesis of Norway spruce (Picea abies [L.] Karst.). In: R. Wimmer \& R.E. Vetter (eds.), Tree-ring analysis: 33-53. CAB International, Oxon, UK.

Iqbal, M. 1994. Structural and operational specializations of the vascular cambium of seed plants. In: M. Iqbal (ed.), Growth patterns in vascular plants: 211-271. Dioscorides Press, Portland, Oregon. 
Kramer, P.J. \& T.T. Kozlowski. 1979. Physiology of woody plants. Academic Press, New York.

Kutscha, N.P., F. Hyland \& J.M. Schwarzmann. 1975. Certain seasonal changes in balsam fir cambium and its derivatives. Wood Sci. Technol. 9: 175-188.

Mahmood, A. 1971. Number of initial-cell divisions as a measure of activity in the yearly cambial growth pattern in Pinus. The Pakistan J. Forestry 21: 27-42.

Oribe, Y. \& T. Kubo. 1997. Effect of heat on cambial reactivation during winter dormancy in evergreen and deciduous conifers. Tree Physiol. 17: 81-87.

Plomion, C., G. Leprovost \& A. Stokes. 2001. Wood formation in trees. Plant Physiol. 127: 15131523.

Pritchard, J. 1994. The control of cell expansion in roots. New Phytol. 127: 3-26.

Rao, K.S. \& K.S. Rajput. 1999. Seasonal behaviour of vascular cambium in teak (Tectona grandis) growing in moist deciduous and dry deciduous forests. IAWA J. 20: 85-93.

Ros Barceló, A., F. Pomar, M.A. Ferrer, P. Martínez, M.C. Ballesta \& M.A. Pedre'no. 2002. In situ characterization of a NO-sensitive peroxidase in the lignifying xylem of Zinnia elegans. Physiol. Plantarum 114: 33-40.

Rossi, S. 2003. Intra-annual dynamics of tree-ring formation and effects of the environmental factors at the timberline in the Eastern Alps. PhD thesis, University of Padova, Italy.

Rossi, S., T. Anfodillo \& R. Menardi. 2006a. Trephor: a new tool for sampling microcores from tree stems. IAWA J. 27: 89-97.

Rossi, S., A. Deslauriers, T. Anfodillo, H. Morin, A. Saracino, R. Motta \& M. Borghetti. 2006b. Conifers in cold environments synchronize maximum growth rate of tree-ring formation with day length. New Phytol. 170: 301-310.

Rossi, S., A. Deslauriers \& H. Morin. 2003. Application of the Gompertz equation for the study of xylem cell development. Dendrochronologia 21: 33-39.

Savidge, R.A. 2000. Intrinsic regulation of cambial growth. J. Plant Growth Regul. 20: 52-77.

Savidge, R.A. 2003. Tree growth and wood quality. In: J.R. Barnett \& G. Jeronimidis (eds.), Wood quality and its biological basis: 1-29. Blackwell Publishing Ltd, Oxford, UK.

Skene, D.S. 1969. The period of time taken by cambial derivatives to grow and differentiate into tracheids in Pinus radiata D. Don. Ann. Bot. 33: 253-262.

Timell, T.E. 1980. Organization and ultrastructure of the dormant cambial zone in compression wood of Picea abies. Wood Sci. Technol. 14: 161-179.

Tsoumis, G. 1991. Science and technology of wood: structure, properties, utilization. Chapman and Hall, New York.

Uggla, C., E. Magel, T. Moritz \& B. Sundberg. 2001. Function and dynamics of auxin and carbohydrates during earlywood/latewood transition in Scots pine. Plant Physiol. 125: 20292039.

Whitmore, F.W. \& R. Zahner. 1966. Development of the xylem ring in stems of young red pine trees. Forest Sci. 12: 198-210.

Wilson, B.F. 1964. A model for cell production by the cambium of conifers. In: M.H. Zimmermann (ed.), The formation of wood in forest trees: 19-36. Academic Press, New York, London.

Wimmer, R. 2002. Wood anatomical features in tree-rings as indicators of environmental change. Dendrochronologia 20: 21-36.

Wodzicki, T. J. 1971. Mechanism of xylem differentiation in Pinus silvestris L. J. Exp. Bot. 22: $670-687$.

Wodzicki, T.J. 2001. Natural factors affecting wood structure. Wood Sci. Technol. 35: 5-26. 